\title{
Mondialisation and Critiques of Capitalism
}

\author{
Bregham Dalgliesh
}

\section{Globalisation and Mondialisation}

Although academics have a penchant for interpreting the present as a "high point" (Foucault 1988: 35), recent analyses of globalisation suggest they might be right. If globalisation initially gestured at interconnectedness, with others so "involved in our lives, as we in theirs," that Marshall McLuhan's (1964: 5) metaphor of a "global village" quickly entered the vernacular, today's more nuanced interpretations of globalisation include hyper-industrialisation, surveillance society, consumerism or hybridisation. Yet the content of concepts is never shorn of context. Beyond Europe and the USA, high points not only concern mutations of global capitalism and the democratic credentials of state power, but also the feasibility of technological projects when the hidden face of progress - the "global [tsunami] accident" (Virilio 1999: 92) - claims its wages. The times we live in, therefore, are "interesting ... [and need] to be ... broken down" (Foucault 1988: 36), and if the task of philosophy is to describe the present and who we are therein, then it is to such an endeavour that this article contributes.

To begin with, and following Peter Sloterdijk's argument in Le palais de cristal: à l'intérieur du capitalisme planétaire,[1] analyses of globalisation are rarely philosophical. An example is the haphazard use of history by "faculty experts" (Agger and Luke 2012) to understand globalisation in a linear fashion, which accounts for notions of rupture in the present that Foucault encourages us to avoid. In the age of the "wired hyperbubble" (Sloterdijk 1997: 57), where we tend to define ourselves in terms of access to networks, we require a spatial approach to globalisation. Reason unfolds in place, not ahistorical space, which explains Sloterdijk's (2006: 1) view of philosophy as the activity that "grasps its place in thought."

Similarly, critique is missing from most non-philosophical debates. Even Sloterdijk (2006: 216), for whom "[c] ontesting globalisation is also part of globalisation itself," only considers terrorism as a by-product of the burgeoning "global imaginary" (Steger 2009: 10). Other criticisms of this hue abound, but it is rare to see authors stand back and reflect upon how to criticise globalisation. One recent exception is Benjamin Noys (2010). In his article, "'Grey in Grey': Crisis, Critique, Change," he highlights the aporia of vitalist critiques of capitalism. In refusing to acknowledge how capitalism weathers its crises and creatively consumes its contradictions, they fail to understand how it intellectually disarms them, too. Yet while Noys draws our attention to the need for a critique of global capitalism, he does not articulate the form it might take.

The aim here is to suggest one in the shape of critical history, which necessitates factoring the role of technology into the power relations at the heart of globalisation.[2] Precisely because of the capacity of power in tandem with technology to constitute the practices in which our everyday experiences are played out, we introduce the concepts of technoglobalism and power/technoscience. These allow us to account for the ethico-political effects of globalisation. Further, an eclectic interdisciplinary approach is adopted in which we treat theory and books as strategic tools. [3] While partly warranted by the complexity of the phenomenon of globalisation, it is justified by the need to develop a critique that fosters mondialisation.

In this respect, globalisation to date has been a Westernised process of discovery and appropriation. The result, Jean-Luc Nancy (2007: 34) argues, is that we have lost the ability to "form a world" and instead become adept at 
"proliferating ... the "unworld'."[4] In this sense, globalisation is "the name for a crisis" (Nowotny 2003) bought about by the "common [global] administration" of capitalism (Tassin 2003). It suffocates the globe, or makes it into nothing other than its double, a "glomus." [5] Mondialisation is a philosophical response to globalisation's "dehumanisation through [despatialised] planetarisation" (Teilhard de Chardin quoted in Capdepuy 2011).[6] As Eric Tassin (2003) argues, we need a world in which "[p]olitics begins with the establishment of a relation to what is outside [the economy]." On this understanding, mondialisation is an attempt to recreate the world, such that "one finds oneself ... [and] can be in it with 'everyone"” (Nancy 2007: 41).[7] As an open-ended process, Jacques Derrida (1998) suggests mondialisation is a work-in-progress of "humanisation." In contradistinction to the actual of the globe, cosmos or universe, the "worldwidisation of the world" is a virtual and ongoing task for critique, which seeks to instantiate mondialisation, or our "becoming-worldly" (Derrida 1998).

In short, if globalisation leaves nothing outside of itself and subjugates local spaces to an abstract, global logic of markets, technologies and homogenising modes of human interaction - hence the feeling of "being globalised" (Bauman 1998: 59) in a "run-away world" of anonymous forces (Giddens 1999) - then critique can offer the hope of a world "in which there is room for everyone" (Nancy 2007: 42). As Paul Valery wrote in Regards sur le monde actuel (1931), "[t]he time of a finite world is beginning," and critique can create the conceptual landscape for its manifestation as mondialisation.

\section{| Globalisation and The Question of Power}

Popularised - but not invented (Feder 2006) - by Theodore Levitt (1983), globalisation has become the academic buzzword in a litany of controversies, from climate change and deregulated financial markets to quadrennial sports events. Following Levitt, globalisation still concerns various economic phenomena, yet their social and ethico-political impact has increased with the spatio-temporal shrinkage of the world by new information and communication technologies (NICT).[8] Indeed, "global" is now indicative of the worldwide diffusion of common cultural experiences and ethico-political forms of subjectivation, from social networking and ubiquitous brands to repetitive patterns of consumption and historical events, whether $9 / 11$ and $7 / 7$, or 3/11(/04) and 3/11(/11).[9]

Building on David Held's and Anthony McGrew's analytical categories, we can discern the globalist, the sceptic and the mondialist.[10] These distinctions are useful for pinpointing the ethico-political problem of globalisation as "a process which universalises technology, economy, politics, and even civilisation and culture[, yet] ... remains somewhat empty [because, as Kostas Axelos (2005: 27) argues, t] he world as an opening is missing."

The globalist highlights economic indicators to produce league tables of the world's most globalised states. Pride of place is reserved for Singapore, Hong Kong and The Netherlands, with the wooden spoon shared between Brazil, India and Iran (Kearney/Foreign Policy 2007). In a similar vein, the globalist earmarks failed states. Sudan, the Democratic Republic of Congo or Ivory Coast miss out on globalisation's economic fruits because of protectionism, pre-modern socio-economic structures and anti-Western sentiments (Fund for Peace 2006). There are more nuanced indices of globalisation, notably the KOF Index of Globalisation, which treats globalisation as a historical "process of creating networks ... [and] complex relations of mutual interdependence” (Dreher 2006). Still, with the globalist we end up with a definition of globalisation as an evolutionary, hence necessary, economic and political rupture.

Because the globalist views globalisation through a politico-economic lens that discerns progressive epochs in the history of capitalism, it soon engenders the wrath of the sceptic. From this perspective, globalisation implores action subsequent to a moral reflection upon the economic consequences of its enforced peace, whether at the local, regional, national or international level.[11] Amongst other concerns about "market globalism['s]" (Steger 2009: 20) ideology of a "New World Order" (Steingard and Fitzgibbons 1996), there is unease about the shift of power from nation-states to international organisations and multinational corporations; the pooling of sovereignty by nation-states in supranational institutions, with the European Union perhaps the best example;[12] and a neo-liberal orthodoxy that equates progress with economic growth and the extension of the free market (Bauman 2008: 3-9).

The worry for the sceptic is that, in a sleight of ideological hand that forces us to embrace the contingent as necessary, TINA (There Is No Alternative) comes to define our politico-moral horizons (Bauman 2001: 6-8).[13] The increasingly global conditions of our possibility are rendered sacred with any act to profane them seen as "leading straight to the gulag" (Bauman 1999: 4). Rephrasing Marx's insight that people make history, though not under conditions they choose, Zygmunt Bauman (2001: 7) detects the ethical cost of "individuals by decree," or a form of 
subjectivity where the object of government is oneself. Yet for the "self-entrepreneur" (Gorz 2003: 24-26) solipsistic government is not under conditions of her choice. Self-policing politicians of everyday life cannot at the same time be members of a polity, which although historically concerned with the fine-tuning of these conditions, now focuses on controlling those citizens that refuse the decree to be individual.[14]

For the sceptic, therefore, globalisation is a double-edged sword. On the one edge, there is an intra-state impasse. Individuals are incited to practice freedom without limits, or licence, which is mirrored by the absence of political will to transgress the limits of the TINA neo-liberal global order. These, in turn, are distinctly off-limits to criticism. On the other edge, the extra-state predicament is that we are confronted with markets striving to become global, while the institutions that oversee them remain national (Rodrik 2000: 348). Under such conditions, Joseph Stiglitz (2002) aptly notes, we end up in a situation characterised by global (economic) governance without global government. [15] Further, as José Gabriel Palma (2009: 830) points out, a demon is required for these conditions to be accepted as ideal, and in the case of neo-liberalism's efficient capital market theory it is governments that are exogenous to the model. In short, power beyond sanction takes leave of the democratically legitimated power to sanction. As Bauman (2003: 15, italics in the original) argues, "power rules because it ... is able ... to flow away. Power superiority, domination, consist these days in the capacity of disengaging."

Our brief excursus suggests that, if we want to bring critique to bear on globalisation, we need to think beyond the stalemate between the globalist and sceptic. The former celebrates globalisation qua liberalisation and internationalisation, which explain the economic ruptures wrought by neo-liberalism, together with its taming of government (Scholte 2000). For the sceptic, however, the focus is on globalisation as the high point of the long-run political and cultural processes of modernisation and universalisation, respectively (Hirst and Thompson 1996).[16] As such, the globalist versus sceptic dispute is arguably one between the fraternal enemies of Right and Left, or a first way driven by capital that is inherently proactive and a second way destined to be reactive in the name of the ontological diremption the former causes.

An alternative perspective of the mondialist is therefore necessary. The mondialist does not, pace the globalist, reduce globalisation to an economic logic, but instead sees it as an historical process that, contra the sceptic, has unique and distinctive attributes in the present. These are "the spatial re-organization and re-articulation of economic, political, military and cultural power" (Scholte 2000: 46), or deterritorialisation. By transforming the scale of human togetherness, globalisation "extends the reach of power relations across the world ... [to such an extent that] globalisation ought primarily to be about the question of power: its modalities, instrumentalities, organisation and distribution" (Held and McGrew 2001).[17]

\section{Technoglobalism and Neo-Schumpeterian Economics}

In this light, the first question for the mondialist concerns how technology impacts upon power, as well as how, in tandem, they shape our modes of self-formation? The challenge is to understand globalisation as an ethicopolitical problem and to push it towards a resolution in mondialisation. To this end, we must first deepen the insight of power as the crux of the issue by outlining a primarily technological conceptualisation of globalisation.

Daniel Archibugi and Jonathan Mitchie have coined the term "technoglobalism" to capture some of the main trajectories of technology at the planetary level today. By technoglobalism, Archibugi and Mitchie (1995: 121) mean "the phenomenon of 'globalisation' experienced by the world of invention and innovation." [18] From the perspective of economics, Archibugi and Iammarino (2002: 99) assume this phenomenon is uncomplicated, because "technological knowledge transmission among peoples ... [meets] less resistance than occurred in the cases of cultural, religious, social and political habits." This is not to say that the diffusion of technology takes place in a barrier free world, as problems of tacit knowledge, access to technology, learning how to use it and paying for that privilege remain (Archibugi and Pietrobelli 2003: 862-864).[19] Rather, technoglobalism implies technology is the driving force behind globalisation, both in terms of its NICT driven space-time conflation and the impotence of any barriers to it, such as the nation-state, whether in its sovereign moment (Edgerton 2007) or role as regulator (Florida 1995).[20]

Technoglobalism brings technology to the fore as one of globalisation's conditions of possibility. Yet it makes no allusion to the socio-economic and political framework that facilitates the diffusion of technology, which is necessary to comprehend how technoglobalism engenders a "complexity of new ways of interaction ... between 
the socialites composing the planet" (Mattelart 2006: 548). In order to account for technology's socio-economic and political moments, we examine the theoretical insights of evolutionary, neo-Schumpeterian economics.

The obvious point of departure here is Joseph Schumpeter, who also anticipates the aporia of vitalistic critiques of capitalism. To make the political point that the internal dynamics of capitalism are impervious to revolution, Schumpeter focuses on endogenous changes. He challenges the orthodox (Keynesian) explanation of exogenous business cycles, which suggests government can reverse externally generated declines in aggregate demand by using public investment to tweak the economy back to a state of equilibrium (Dehejia and Rowe 1998).[21] For Schumpeter, however, the boom-bust nature of the business cycle is inherent to capitalism. In the evolutionary approach to economics, disequilibrium is the rule, not the exception.[22] Cycles depend on radical, discontinuous innovations, which arise due to the "unremitting efforts of people to improve ... upon their productive and commercial methods" (Schumpeter 1935: 4). Manifest at the micro-level as new products, processes and forms of organisation (Schumpeter 1927: 295), radical innovations both destroy existing industries and, via the entrepreneur in search of monopoly profits, give birth to new sectors of economic activity (McCraw 2006: 239ff.; Salomon et al. 1994, ch. 13).[23] At the macro-level, radical innovations have a cumulative effect on economic growth through a "kind of wave-like movement" (Schumpeter 1935: 4).

Schumpeter's main focus is technological innovation, especially radical innovations that cause the creative destruction of industries and firms. These in turn explain long-run economic cycles of up to fifty years or more.[24] Aligning themselves with the theory of technological change in capitalist economies, scholars at Science and Technology Policy Research (SPRU) extend Schumpeter's analysis through a dynamic model of the diffusion of technological innovation. [25] The SPRU's neo-Schumpeterian claim is that both incremental and radical innovations give rise to new "technology systems" (Perez 2002). These have far-reaching effects on the "behaviour of the entire economy" (Freeman and Perez 1988: 47). During these paradigmatic moments of change, in which technological "styles" (Tylecote 1991: 36) have a Kuhnian "exclusion effect" on alternatives (Dosi 1982: 153), the economic system and socio-institutional framework are both transformed and constitutive. Technology driven change is not solely determined from the bottom-up by science qua explanation and technology qua application,[26] but from the topdown, too, via historically specific socio-economic conditions. These establish a context conducive to the diffusion of technology and channels through which conflict can be managed (Perez 2004).

\section{| Power/Technoscience and The Ethico-political}

Despite its relevance to an explanation of the place of technology in globalisation, the notion of technoglobalism and the SPRU's neo-Schumpeterianism embody a common approach. For a start, technology is treated as a transparent means of exchange for phenomena as diverse as information or culture. Its only noteworthy analytical point is the way in which it facilitates a spatio-temporal flattening. Secondly, technology is presumed to engender change in socioeconomic and political institutions only. Akin to a neutral, extra-human medium that ensures the message in Peking is mirrored in Paris, the effects of technology are limited to the capacity for economic systems and political institutions to facilitate change. Finally, technoglobalism encapsulates the progressivism that is at the heart of liberal democratic societies, where individuals differ about their ends but concur in believing that (objective) technical means are central to (subjective) self-fulfilment (Borgmann 1984: 10-11).

By assuming human beings are ontologically separate from technology, technoglobalism overlooks its influence upon our ontological conditions (Winner 1997). Indeed, this is why our failure to address its ethical aspects might mean the future does not need us.[27] From this ethico-political perspective, technoglobalism's methodological hotspot is its rearticulation of relations of power. These are inescapably ethical via their impact on modes of subjectivation, or the agent producing "procedure by which one obtains the constitution of a ... subjectivity" (Foucault 1988: 253). A critique of globalisation must reveal that technology is not a priori to power, but intertwined with it, as it is this nexus that produces new ethico-political forms.

The import of the analysis is that power relations are subject to transformation by transcontinental flows and interregional networks of technologically driven interaction. Globalisation involves the extra-territorial rearticulation of locally articulated power, which though it has always been everywhere, really now comes from everywhere, too. Power that flows from the bottom-up and the top-down, as well as across the border and over territory, should not be conceived merely as "an institution, [nor] a structure [or] a certain strength we are endowed with;" instead, 
Foucault (1990: 93) continues, power "is the name one attributes to a complex strategical situation." This is not to deny the existence of forms of power that dominate through physical or symbolic violence. Rather, it is to argue that power relations are constitutive of free subjects, which means opening up the ontological to a critique of "the way in which reality is instituted ... as a political process" (Oksala 2010: 447). Such a critique proceeds by making the will to know, here in its guise of the technology that powers globalisation, conscious of itself as a problem, particularly its transformative effects on our ontological conditions.

We can better understand technoglobalism's impact upon the ethico-political by reconceiving the Foucauldian concept "power/knowledge" as "power/technoscience." One reason to substitute technoscience for knowledge is the shift in epistemological justification from a simple curiosity to know, or "mode 1", to "mode 2" and its quasiprivate, instrumental form of knowing (Gibbons et al. 1994; Nowotny, Scott and Gibbons 2001). On this basis, Gilbert Hottois' (1984) original definition of technoscience is useful, which locates science within a technological milieu that is driven by practical considerations. We must cease treating science and technology as separate endeavours, as well as dispel the image of technology as applied science. Rather, technoscience shows how science and technology are tinkering, ordering activities in which defining nature and society are contingent upon the politics of doing technoscience. The "heterogeneous engineer" (Law 1987) develops ever larger networks through acts of translating meaning and enrolling entities to accommodate the interests and strategies of actors. Once achieved, the black boxing of this politics of ontological meaning gives the impression of science and technology as ready-made solutions to pre-existing problems (Latour 1987; Callon 1999). Technoscience shifts us beyond such idealism towards a better approximation of the practice of science and technology.

Finally, to bring us back to technoglobalism's relation to capitalism, technoscience depicts a coalition that personifies the logic of the free market. If the capacity of science to represent things is supported by private capital on condition that the knowledge it produces can be translated into technological innovations, the means through which science achieves its ends is technology (Rabinow 1996: 93). Science represents and technology orders. In the words of Ian Hacking (1983: 146), technoscience represents our world in order to intervene upon reality.[28] The effects for those of us who inhabit this world are obvious because, as Donna Haraway (1997: 51) argues, technoscience shapes "subjectivity and objectivity,... [and] is about worldly, materialized, signifying and significant power."

\section{The Death of The Vitalist Critique of Capitalism}

Technoglobalism's relations of power/technoscience enclose our ways of being in the homogeneity of the glomus, such that the "thing that is called globalisation is a kind of mondialisation without the world" (Axelos 2005: 27). A case in point is NICT media. Driven by profit and deploying techniques of retention, they alter power relations by synchronising the plurality of the subject's diachronic identity with that of the glomus. It reduces the spatiotemporal distance between the agent and structure, which is essential for the self-formation of difference (Stiegler 2009: 75-79). A critique of technoglobal capitalism is therefore urgent, yet the question is what form such a critique should take? Below, we first consider Noys' argument. Although he describes the conundrum that any critique of globalisation must address, he outlines in no more than skeletal form the type of critique that can overcome it. The aim in the final section is to put some flesh on it.

The background to Noys' (2011: 46) intervention is the 2008 financial crisis, which destabilises "the classical coordination of crisis, critique, and change." Despite the urgency of critique, neither the strategic elements that link critique to change, nor the agency necessary to actually make it, are available. The reason is that the strategic elements historically uniting critique with change have relied on vital powers external to capitalism. Noys has several paradigmatic vitalist critiques in mind here. These include the socio-economic conditions of capitalism itself, which Marx envisaged; the productive powers of Michael Hardt's and Antonio Negri's multitude; or Fredric Jameson's metaphysics of time as flux and revaluated ends. In addition, Noys alludes to George Bataille's economy of the excremental, or Alain Badiou's concept of life, as sources of affirmation against capitalism.

Historically, these outsides and excesses have been beyond the grasp of capitalism and so apt to fight its dynamism. However, they now find themselves impotent in the face of an inert capitalism that has run out of steam. Fighting fire with fire is no longer an option. We face, Noys (2011: 55) argues, an aporia in that "neither the radicalisation of the productive forces, nor the resort to anti-production seems able to grasp or escape the 
bewitchment of capitalism as a system of crisis and creative destruction."

Once the anti-capitalist's weapon of critique dies with the beast of dynamic capitalism, what are the alternatives? As Bernard Stiegler (2009: 74) similarly asks, how can we undertake a critique that is radical yet "prohibits itself from diabolising the adversary?" For Noys, the solution is a critique that can grasp the enigmas of the present crisis of capitalism. Noysian critique apprehends our world as it recedes from experience precisely because, at the level of the imaginary, it returns to envelope us as the ontological horizons that constitute our experience. In poststructural parlance, Noys' "grey on grey" of the actuel passé shifts the focus of critique from the epistemological to the ontological level. It ushers the subject back into the picture, though not as the agent of change, but in terms of depicting capitalism's “ecologies of the milieus of spirit” (Stiegler 2009: 75). The strategic elements to hand are an understanding of the structural determinations that often "overwhelm the subject by being cast as potential sources of liberation," together with an account of the potential for individual autonomy, which derives from a mode of critique that "strategically think[s] forms and conditions of resistance against a devalorising and decelerating capitalism” (Noys 2011: 57).

Like Schumpeter, Noys highlights the urgency of a non-vitalist critique that refuses to draw its energy from a realm beyond or outside of capitalism itself. This requires a shift in perspective from an external viewpoint to a position within capitalism that can afford an understanding of its ontological mechanisms. To borrow Sloterdijk's metaphor, we are trapped in our self-styled crystal palace and, even if people in glasshouses should not throw stones, critique commences therein on behalf of those kept outside and disarmed by the processes of "DIP (deregulation, individualization, privatization)" (Bauman and Rovirosa-Madrazo 2010: 52).[29] Unfortunately, Noys does not elaborate further on an internal critique of capitalism. He simply leaves it there, or perhaps as a task to be accomplished.

\section{Foucauldian Critical History}

"Critical history" meets Noys' challenge by linking the strategic elements of experience painted grey with the agent that transforms the world.[30] It also avoids any notion of rupture being discerned from the discredited vitalistic outside, as its "transgressive limit-attitude" (Foucault 1984: 47) puts critique in the service of autonomy by targeting the systems of thought in which the historicity of how we experience ourselves resides.

Critical history can be contrasted with both philosophical critique and the immanent critique of the Frankfurt School. Although critical history is indebted to Kantian philosophical critique, Foucault follows Nietzsche by grounding reason in practices of power. Once the Kantian transcendental standpoint and the possibility of an explicit judgement premised on an analytic of truth are jettisoned, critical history proceeds by making the will to know conscious of itself as a problem. It hereby implores from those implicated critique's concrete, political moment of transformation. Instead of being transcendental and concerned with the possibility of metaphysics, critical history is archaeological and concerned with a genealogy that etches out spaces of freedom. Rather than a formal critique undertaken to necessarily limit the remit of reason, critical history is a practical critique preoccupied with the possibility of transgressing those limits - such as today's glomus - by showing their contingency (Foucault 1984: 45-47).

Insofar as critical theory is concerned, Foucault does not entertain a privileged, transcendental perspective for truth. The critical historian is situated inside practice and thus unable to speak on behalf of others from an outside perspective (Foucault 1977: 209). Further, the domain of the political is as much intra- as extra-state, not least because Foucault is analysing, firstly, the sovereign power targeted by the critical theorist, as well as its inextricable relation to knowledge; and, secondly, the biopower that critical history reveals to be coterminous with its sovereign sibling. As we can see, both these aspects coincide with Noy's call for a critique that can no longer defer to vitalistic resources from a position outside of capitalism for its strategy, while the conception of power that flows under as well as over borders allows us to expand the domain of the political to incorporate the global, too.

In this guise, philosophy makes the insatiable human appetite for technoscience aware of the concomitant forms of domination its politics engenders. Having become nothing short of a duty in today's technology powered global economy, this tradition can be traced back to Friedrich Nietzsche (1899: 220) who, in the Genealogy of Morals, anticipates the day when the "will to truth has become conscious of itself as a problem." Foucault's contribution is to bridge the will to power with the will to knowledge through his concept of the apparatuses of (what we have 
expanded to) power/technoscience. In his move beyond Kant and Nietzsche, Foucault's critical history gives the will to know a consciousness of itself as a problem in terms of the limits these apparatuses establish for subjects.

On this understanding, Foucault offers a transformative critique that has two interrelated moments of ideal criticism and real transformation, or the potential to bridge critique and change to which Noys draws our attention. Ideal critique is less a question of denouncing what is wrong than excavating on "what kinds of ... unchallenged modes of thought the practices we accept rest" (Foucault 1988: 154). It allows us to pursue mondialisation by giving sense and meaning to everyday experience. As "the means to think the world as it is and as it could be" (Wacquant 2004: 98; italics in the original), critique avoids "human possibilities worth pursuing ... from being foreclosed" (Bauman 2001: 12). It seeks to make "facile gestures difficult," with ideal critique succeeding to the extent that it leads to the second moment of real transformation, for "as soon as one can no longer think things as one formerly thought them, transformation becomes ... quite possible” (Foucault 1988: 154).

\section{| Conclusion: Critique and The Ethico-political Effects of Globalisation}

If, for the mondialist, events from distant places diffuse as strategies of power/technoscience that constitute ontological contexts in far away spaces, what this critical excursus into technoglobal capitalism reveals is the absence in debates about globalisation of a politics of technology. Langdon Winner (1989: 20-22) and others (Feenberg 1999; Hess 1995) have talked of the need for a "theory of technological politics," which asks not only how artefacts and socio-technical systems change, but also how they impact upon individuals and their social world.[31] Such an endeavour would complement studies of technological systems by examining the social and ethical repercussions of technoglobalism. Part of this project would be an understanding of technology's inextricable relation to power, henceforth to be thought of as relations of power/technoscience. A critique of globalisation, such as that called for by Noys in respect of capitalism's crisis of stasis that disables vitalistic modes of criticism, must illuminate this silence by articulating the strategic elements that link certain forms of power to specific technological systems so that (ideal) critique can provide the fuel for resistance and (concrete) change.

Needless to say, a critical history of globalisation that heeds this call is neither technophobe nor technophile. Rather, the cue is an acceptance of technology's burgeoning role in repositioning finitude's horizon, while the spur is a scepticism that seeks to counter-balance the optimism of globalisation's adept academics - the globalists - and spaced out elites, who remain deliberately out of place. Unlike the sceptic, the mondialist's critique is methodologically agnostic about technology: because it is omnipresent, "as much in the real as in the imaginary[, ... f]riendship towards technology ... is a present and future task" (Axelos 2005: 28).

To this end, we must begin once again to interpret the world, because if we want to make a difference through choices that come from apprehending and seeking to change the changes, it "cannot take place other than through a critique of what in the process [viz. technoglobalism] condemns the process itself" (Stiegler 2009: 72). In any case, as Günther Anders realised, the world changes, mostly without our effort and often due to technology. The task is to grasp "these changes so we in turn can change the changes, so that the world doesn't go on changing without us - and not ultimately become a world without us" (Anders quoted in Schraube 2005: 78). In this sense of technoglobal capitalism as a process to be understood rather than a puzzle to be pieced together, critique is wager against globalisation and for mondialisation. The challenge for critical history is to complement what until now has been mostly “'negative' globalization ... by its 'positive' counterpart (as, for instance, globalization of political representation, law and jurisdiction)" (Bauman 2010: 204). Mondialisation, or a world to which we belong and in which we want to be, is arguably the condition for these positive counterparts.

\section{Endnotes}

1. We keep the French title of Peter Sloterdijk's 2005 book, Im Weltinnenraum des Kapitals. Für eine philosophische Theorie der Globalisierung, as the metaphor of a "crystal palace" comes in handy later (all translations of this and other French texts are my own).

2. For the purposes of this article, "technology" refers to a socio-technical system of manufacture 
(or organisation) and use (individual and social) that extends human capacities.

3. Foucault (1994: 523) requests that others treat (his) books as a toolbox to "rummage through." The tools of thought "must be useful [and] ... function." (Deleuze quoted in Foucault 1977: 208), such that we deploy texts as our "pair of glasses directed to the outside" (Marcel Proust cited by Deleuze, quoted in Foucault 1977: 208) world of globalisation and thought as our "screwdriver or spanner to short-circuit [and] discredit [its] systems of power" (Foucault 2004).

4. Nowotny (2003) distils three interrelated components of "world" from the thought of Nancy: it is a "resonance space" in which we come into existence; it is our habitat, or where we have our place and participate; finally, "world" is where meaning is to be found and, indeed, it is radically immanent to it.

5. "In such a glomus, we see the conjunction of an indefinite growth of techno-science, ... of a worsening of inequalities ... - economic, biological, and cultural - and of the dissipation of the certainties, images, and identities of what the world was with its parts and humanity with its characteristics" (Nancy 2007: 34).

6. See Capdepuy (2011), whose archaeology of mondialisation reveals its chequered career as, initially, a concept of Eurocentric progressivism and, since the 1990 s, as a synonym for globalisation and (as we deploy it here) a potential critical alternative to it.

7. Devisch (2006) argues Nancy is a philosopher of sense-seeking, singular plural being (Being as Beingwith), which makes him a thinker of the "way in which we are [inescapably part of the] world". Nancy's "world" signifies a Heideggerian background in which the subject is always already ontologically and symbolically a being-with others. What globalisation does is to expand our horizons of sense, such that we are thrown into a situation of becoming-worldwide through our sudden and radical exposure to new modes of being and symbolic vistas (Devisch 2006; also see Meurs, Note and Aerts 2009).

8. NICT are distinguished by digitalisation, which has transformed both communication and society into despatialised "informational" (Lash 2002), "networked" (Castells 2004) phenomena that are characterised by the "death of distance" (Cairncross 1997).

9. Just how global our experience is remains a question of perspective. If most readers are familiar with $9 / 11$ and, to a lesser degree, 7/7, 3/11 no doubt means very different things in Spain and Japan. We should also note the extent to which the American month-day-year date format has come to dominate our imaginary since $9 / 11$ : had the $7 / 7$ bombings occurred a day earlier in London, for instance, would we today speak of $6 / 7$ or $7 / 6$ ?

10. Held and McGrew (2001) first distinguished hyperglobalisers, sceptics and transformationalists, and later the globalist, sceptic and cosmopolitan (Held and McGrew 2012). In contrast, we use mondialist to indicate an advocate of mondialisation, which is partly derived from "alter-mondialisation" (Ramonet 1998). However, an alter-mondialist denotes an "alternative globalisation" and is essentially a movement, whereas the activity of a mondialist is rhizomatic thinking beyond the globalist-sceptic debate.

11. For example, Gray (1999), Landes (1999) and Frank (2002).

12. See, in this respect, the reports by the European Commission $(2003 ; 2006$; 2007) on the European single market or economic and monetary union, or the visions of Jacques Delors (1989: ch. II, sec. 5) or Roy Jenkin (1977).

13. As the globalist counsels (with some exceptions, for instance, Kenichi Ohmae [1990]), countries must don a "Golden Straitjacket" and accept that policy choices are reduced to Pepsi or Coke: "slight nuances of policy, slight alterations in design to account for local traditions ... but never any major deviation from the core golden rules" (Friedman 1999: 87).

14. Bauman (2001: 7-8) uses critique to articulate the boundary between structure and agency, as well as to speak out against their dissociation. We might contrast this with a crude Marxism's will to distinguish structure as the determinant of agency, and neo-liberalism's will to divorce agency from structure. As Jacques Donzelot (1991) shows, the latter shifts social risk from the collective indemnification of the individual on behalf of society to the individual's new civic obligation to minimise the risks she imposes on society.

15. As always, there are exceptions to the rule. Reinicke (1998), as a case in point, traces the emergence of global policy under the control of nation-states in the domains of transnational crime, dual-purpose civilmilitary goods and financial markets. Deacon, Hulse and Stubbs (1997), Dicken (1998) and Mishra (1999) make similar cases.

16. Of course, the sceptic explains these politicocultural processes as a function of the economic (which is the sole concern of the globalist). As Marx and Engels (1967, p. 18) famously claimed, the economic processes of liberalisation and internationalisation, or "the need of a constantly expanding market for ... products [that] chases [business] over the entire surface of the globe," engender the politico-cultural consequences of modernisation and universalization: "[i]n place of the old local and national seclusion and self-sufficiency, we have intercourse in every direction, universal interdependence of nations."

17. Giddens (1990: 60ff.) and Held et al. (1999) argue likewise.

18. Archibugi and Mitchie (1995) and Archibugi and Iammarino (2002) detect three paths in this 
process: the global exploitation of nationally produced technology; global techno-scientific collaboration; and, thirdly, the global generation of technology.

19. While there is relative convergence in the global assimilation of older technologies, for example, telephony and electricity, there is divergence in the global assimilation of new technologies, such as biotechnology or NICT (Archibugi 2005).

20. Technoglobalism can be distinguished from technonationalism (Montresor 2001). Although these terms originate as descriptive categories in science and technology policy debates in the 1990s (Ostry and Nelson 1995; Keller and Samuels 2002: 7-9), technonationalism's shortcoming is its claim that the nation-state is key for understanding cultures of innovation and the diffusion of technology.

21. There are several post-Keynesian explanations of the boom-bust nature of business cycles. Some focus on endogenous factors, namely, rational expectations about future economic outcomes that affect present levels of investment, or (from the monetarist perspective) government induced changes in money supply, while others concentrate on exogenous factors, such as natural disasters, the power of cartels to determine the price of key input factors or, for the neo-liberal, government intervention itself (Hall 1990; Palma 2009).

22. Here, evolution is the auto-transformation of a system through the internal production and diffusion of novelty. See Dosi, Orsenigo and Labini (2002), Nelson (2003), Nelson and Winter (1982) and Witt (2003).

23. The mechanism of natural selection in the evolution of capitalism is radical innovation, whose creative gales of destruction are fanned by the innovative and entrepreneurial. It is the origin of innovation in new technologies, rather than a drop in aggregate demand or a rise in prices due to a change in the money supply or interest rates, which determine capitalism's boom-bust cyclical evolution. Technology, Schumpeter assumes, Robert Solow (1957) backs up and Gerhard Mensch (1979) underlines, is an endogenous - and for many today, including Paul Krugman (1986) and Paul Romer (1990; 1986: 1003), the key - factor of production.

24. For reservations about the explanatory power of technological innovations, see Rosenberg and Frischtak (1994).

25. On the basic tenets of the SPRU approach, see Freeman (1992: 81-133), Freeman, Clark and Soete (1982), Dosi (1988), Freeman and Soete (1997), and Freeman and Louçã (2001).

26. This is standard approach of scholars of the economics of innovation, for instance, Littler (1988), McGinn (1991) and Tidd, Bessant and Pavitt (2005).

27. Bill Joy (2000) condemns the lack of social and ethical dialogue on the human purposes of NICT. For others, notably Anders (2002), it is already too late and humanity is all but obsolete.

28. On the modes through which technoscience can change the world, see Kastenhofer and Schmidt (2011).

29. Recounting Dostoevsky's visit to the Great Exhibition of 1851, Sloterdijk (2006: 33) suggests London's Crystal Palace personifies a self-satisfied society enclosing itself in comfort, which is destined to pay the price of a psychological stripping bare of its inhabitants. As a metaphor of the destiny of both capitalism and communism, Sloterdijk claims that for the former the acclimatised luxury of the glasshouse is indicative of the rendering of work, desire and culture into a base capacity to consume.

30. For a full discussion, see Dalgliesh (2013).

31. As Winner argues (1980: 125 and 128), the "things we call 'technologies' ... contain possibilities for many different ways of ordering human activity. The issues that divide or unite people in society are settled not only in the institutions and practices of politics proper, but also, and less obviously, in tangible arrangements of steel and concrete, wires and transistors, nuts and bolts."

\section{References}

Agger, Ben and Luke, Timothy W. 2012. Occupy Globalization. Fast Capitalism, 9 (1). http://www.uta.edu/huma/agger/ fastcapitalism/9_1/aggerluke9_1.html. Accessed 12 June 2013.

Anders, Günther. 2002. L'obsolescence de l'homme - sur l'âme a l'époque de la deuxième révolution industrielle. Paris: Editions de l'Encyclopédie des Nuissances.
Archibugi, D. 2005. Current Research in Innovation Studies. SPRU seminars (Sussex University). http://www. danielearchibugi.org/teaching/seminars\%5Fspru/. Accessed 10 July 2009.

Archibugi, D. and Iammarino, S. 2002. The Globalisation of Technological Innovation: Definition and Evidence. Review of International Political Economy, 9 (1): 98-122. 
Archibugi, D. and Michie, J. 1995. The Globalisation of Technology: A New Taxonomy. Cambridge Journal of Economics, 19 (1): 121-140.

Archibugi, D. and Pietrobelli, C. 2003. The globalisation of technology and its implications for developing countries. Windows of opportunity or further burden? Technological Forecasting and Social Change, 70: 861-883.

Axelos, Kostas. 2005. Mondialisation Without the World. Radical Philosophy, 130 (March/April): 25-28.

Bauman, Zygmunt. 1998. Globalisation: The Human Consequences. New York: Columbia University Press.

Bauman, Zygmunt. 1999. In Search of Politics. Cambridge: Polity Press.

Bauman, Zygmunt. 2001. The Individualised Society. Cambridge: Polity Press.

Bauman, Zygmunt. 2003. City of Fears, City of Hopes. London: Goldsmiths College/University of London. http://cms.gold. ac.uk/media/city.pdf. Accessed 11 October 2010.

Bauman, Zygmunt. 2008. The Art of Life. Cambridge: Polity Press.

Bauman, Zygmunt. 2010. Conclusion: The Triple Challenge. In M. Davis and K. Tester (eds), Bauman's Challenge: Sociological Issues for the 21st Century. Houndsmill: Palgrave Macmillan, 200-205.

Bauman, Zygmunt and Rovirosa-Madrazo, Citlali. 2010. Living on Borrowed Time: Conversations with Citlali Rovirosa-Madrazo. Cambridge: Polity Press.

Borgman, Albert. 1984. Technology and the Character of Contemporary Life: A Philosophical Inquiry. Chicago: Chicago University Press.

Cairncross, Frances. 1997. The Death of Distance: how the communications revolution is changing our lives. London: Texere Publishing Limited.

Callon, Michel. 1999. Some elements of a sociology of translation: domestication of the scallops and the fishermen of St. Brieuc bay. In M. Biagioli (ed.), The science studies reader. New York and London: Routledge, 67-83.

Capdepuy, Vincent. 2011. Au prisme des mots. Cybergeo: European Journal of Geography. (Epistemology, History, Teaching). http://cybergeo.revues.org/24903. Accessed 18 July 2013 .

Castells, Manuel. 2004. Informationalism, Networks, and the Network Society: A Theoretical Blueprint. In M. Castells (ed.), The Network Society: A Cross-cultural Perspective. Cheltenham, UK: Edgar Elgar, 3-48.

Dalgliesh, B. (2013). Critical History: Foucault After Kant and Nietzsche. Parrhesia: A Journal of Critical Philosophy, 18: 68-84.
Deacon, Bob, Hulse, Michelle and Stubbs, Paul. 1997. Global Social Policy: International Organisations and the Future of Welfare. London: Sage.

Dehejia, V. H. and Rowe, N. 1998. The Effect of Business Cycles on Growth: Keynes vs Schumpeter. Economic Inquiry, 36 (3): 501-511.

Delors, Jacques. 1989. Committee for the Study of Economic and Monetary Union. http://ec.europa.eu/economy_finance/ euro/origins/delors_en.pdf. Accessed 16 August 2009.

Derrida, Jacques. 1998. L'Université sans condition. Presidential Lectures (Stanford University). http://www.jacquesderrida. com.ar/frances/universite.htm. Accessed 23 June 1013.

Dicken, Peter. 1998. Global Shift: Transforming the World Economy (3rd edition). New York: Guildford Press.

Donzelot, J. 1991. Pleasure in work. In G. Burchell, C. Gordon and P. Miller (eds), The Foucault Effect: Studies in Governmentality. Chicago: Chicago University Press, 251-280.

Dosi, G. 1988. Sources, Procedures and Microeconomic Effects of Innovation. Journal of Economic Literature, 26: 1120-1171.

Dosi, G., Orsenigo, L. and Labini, M. S. 2002. Technology and the Economy. LEM Working Paper 2002/18. http://www.lem. sssup.it/WPLem/files/2002-18.pdf. Accessed 19 July 2009.

Dosi, Giovanni. 1982. Technological paradigms and technological trajectories: a suggested interpretation of the determinants and direction of technical change. Research Policy, 11 (3): 147-162.

Dreher, Axel. 2006. Does Globalization Affect Growth? Evidence from a new Index of Globalization. Applied Economics, 38 (10): 1091-1110.

Devisch, Ignaas. 2006. The Sense of Being(-)With Jean-Luc Nancy. Culture Machine, 8. http://www.culturemachine.net/ index.php/cm/article/viewArticle/36/44. Accessed 8 July 2013.

Edgerton, D. E. H. 2007. The Contradictions of TechnoNationalism and Techno-Globalism: A Historical Perspective. New Global Studies, 1 (1): 1-32.

European Commission. 2003. Making Globalisation Work for Everyone: The European Union and world trade. Brussels: European Commission.

European Commission. 2006. Better Off in Europe: How the EU's single market benefits you. Brussels: European Commission.

European Commission. 2007. One Currency for One Europe. Brussels: European Commission.

Feder, Barnaby. 2006. Theodore Levitt, 81, Who Coined the Term 'Globalization', Is Dead. New York Times (6 July). http://www.nytimes.com/2006/07/06/business/06levitt. html?_r=0. Accessed 29 July 2013. 
Feenberg, Andrew. 1999. Questioning Technology. New York: Routledge.

Florida, Richard. 1995. Technology Policy for a Global Economy. Issues in Science and Technology, (Spring): 49-56.

Foucault, Michel. 1977. Language, Counter-Memory, Practice: Selected Essays and Interviews. Introd. and Trans. D. F. Bouchard and S. Simon. Oxford: Basil Blackwell.

Foucault, Michel. 1984. What is Enlightenment? In P. Rabinow (ed.), The Foucault Reader. New York: Pantheon Books, 32-50.

Foucault, Michel, 1988. Politics, Philosophy, Culture: Interviews and Other Writings 1977-1984. Introd. and Trans. L. D. Kritzman and A. Sheridan et al. New York and London: Routledge.

Foucault, Michel. 1990. The History of Sexuality, Volume One: An Introduction. Trans. R. Hurley. Harmondsworth: Penguin Books.

Foucault, Michel. 1994. Dits et Écrits, Tome II: 1954-1969. D. Defert et F. Ewald (dirs). Paris: Éditions Gallimard.

Foucault, Michel. 2004. Les confessions de Michel Foucault: Un entretien inédit avec l'un des grands penseurs du XXème siècle (propos recueillis par Roger Pol-Droit en juin 1975). Le Point, (1659): 82-93.

Frank, T. 2002. One Market Under God. Extreme capitalism, market populism, and the end of economic democracy. London: Vintage.

Freeman, C. 1992. The Economics of Hope: Essays on Technical change, Economic Growth and the Environment. London: Pinter.

Freeman, C. and Louçã, F. 2001. As Time Goes By: From Industrial Revolutions to Information Revolution. Oxford: Oxford University Press.

Freeman, C. and Soete, L. 1997. The Economics of Industrial Innovation. Cambridge, Mass.: MIT Press.

Freeman, C., Clark, J. and Soete, L. 1982. Unemployment and Technical Change. London: Frances Pinter.

Freeman, Christopher and Perez, Carlota. 1988. TechnoEconomic Paradigms. In G. Dosi et al. (eds), Technical Change and Economic Theory.London and New York: Pinter Publishers 38-66.

Freitag, Michel. 2010. L'avenir de la société: globalisation ou mondialisation? SociologieS (Découvertes/Redécouvertes). http://sociologies.revues.org/337929. Accessed 27 July 2013.

Friedman, Thomas. 1999. The Lexus and the Olive Tree: Understanding Globalization. Farrar: Harper Collins.

Fund for Peace. 2006. Failed States Index 2006. http://www. fundforpeace.org/programs/fsi/fsindex2006.php. Accessed 22 August 2010.
Gibbons, M., Limoges, C., Nowotny, H., Schwartzman, S., Scott, P. and Trow, M. 1994. The new production of knowledge : the dynamics of science and research in contemporary societies. Newbury Park, CA: Sage.

Giddens, Anthony. 1990. The Consequences of Modernity. Stanford: Stanford University Press.

Giddens, Anthony. 1999. BBC Reith Lectures 1999: Runaway World. http://www.bbc.co.uk/radio4/reith 1999/. Accessed 10 January 2008.

Gorz, André. 2003. L'Immatériel: variation sur le thème de la production de soi. Paris: Galilée.

Gray, John. 1999. False Dawn: The delusions of global capitalism. London: Granta.

Hacking, Ian. 1983. Representing and intervening. Introductory topics in the philosophy of natural science. Cambridge: Cambridge University Press.

Hall, T. E. 1990. Business Cycles: The Nature and Causes of Economic Fluctuations. New York: Praeger Publishers.

Haraway, Donna. 1997. Modest_witness@second_millennium. Femaleman_meets_oncomouse: Feminism and Technoscience. New York and London: Routledge.

Held, D., McGrew, A., Goldblatt, D. and Perraton, J. 1999. What is Globalisation? http://www.polity.co.uk/global/ whatisglobalization.asp. Accessed 14 July 2010.

Held, David and McGrew, Anthony. 2001. Globalisation. In J. Krieger (ed.), Oxford Companion to Politics of the World. Oxford: Oxford University Press, 324-370.

Held, David and McGrew, Anthony. 2012. Globalization/AntiGlobalization. Beyond the Great Divide. Cambridge: Polity.

Hess, D. J. 1995. Science and Technology in a Multicultural World. The Cultural Politics of Facts and Artefacts. New York: Columbia University Press.

Hirst, Paul and Thompson, Graham. 1996. Globalization in Question: The International Economy and the Possibilities of Governance. Cambridge: Polity Press.

Hottois, Gilbert. 1984. Le signe et la technique. La philosophie a l'épreuve de la technique. Paris: Aubier.

Iammarino, S. and Mitchie, J. 1998. The Scope of Technological Globalisation. International Journal of the Economics of Business, 5 (3): 335-353.

Jenkins, Roy. 1977. Europe's Present Challenge and Future Opportunity. Jean Monnet Lecture, Florence, 27 October 1977. http://ec.europa.eu/economy_finance/emu_history/ documentation/chapter9/19771027en17casemonetaryunion. PDF. Accessed 16 August 2009.

Joy, Bill. 2000. Why the future doesn't need us. Wired Magazine (April). 
Kastenhofer, K. and Schmidt, J. C. 2011. Technoscientia est Potentia? Poiesis \& Praxis, 8 (2-3): 125-149.

Kearney, A.T./Foreign Policy. 2007. Globalization Index 2007. http://www.atkearney.com/images/global/pdf/GIndex_2007. pdf. Accessed 24 August 2010.

Keller, William W. and Samuels, Richard J. 2002. Innovation and Crisis in Asia. MIT Japan Program Working Paper 02.03. http://mit.edu/mit-japan/outreach/working-papers/WP0203. pdf. Accessed 9 July 2010.

Krugman, Paul R. 1986. Introduction: New Thinking about Trade Policy. In P. Krugman (ed.), Strategic Trade Policy and the New International Economics. Cambridge, Mass.: MIT Press, 1-22.

Landes, D. 1999. The Wealth and Poverty of Nations. Why some are so rich and some are so poor. London: Abacus.

Lash, Scott. 2002. Critique of Information. London: Sage.

Latour, Bruno. 1987. Science in Action: How to Follow Scientists and Engineers through Society. Cambridge, MA: Harvard University Press.

Law, J. 1987. On the social explanation of technical change: the case of the Portuguese maritime expansion. Technology and Culture, 28 (2): 227-252.

Levitt, Theodore. 1983. The Globalisation of Markets. Harvard Business Review (May-June).

Littler, D. 1988. Technological Development. Oxford: Philip Alan.

Marx, Karl and Engels, Friedrich. 1967. The Communist Manifesto. Trans. Samuel Moore. Harmondsworth: Penguin.

Mattelart, A. 2006. Realpolitik and Utopias of Universal Bonds: For a Critique of Technoglobalism. In A. N. Valdivia (ed.), A Companion to Media Studies. Oxford: Blackwell Publishers, 548-564.

McGinn, R. E. 1991. Science, Technology and Society. Englewood Cliffs, USA: Prentice Hall.

McLuhan, Marshall. 1964. Understanding Media: The Extensions of Man. New York: McGraw Hill.

Mensch, G. 1979. Stalemate in Technology: Innovations overcome the depression. New York: Ballinger.

Meurs, Pieter, Note, Nicole and Aerts, Diederik. 2009. This world without another. Jean-Luc Nancy and la mondialisation. Journal of Critical Globalisation Studies, 1: 31-46.

Mishra, R. 1999. Globalization and the Welfare State. London: Edward Elgar.

Montresor, S. 2001. Techno-globalism, techno-nationalism and technological systems: organizing the evidence. Technovation, $21(7): 399-412$.
Nancy, Jean-Luc. 2007. The Creation of the World, or Globalization. Trans. and Intro. F. Raffoul and D. Pettigrew. Albany, New York: State University of New York Press.

Nelson R. R. and Winter, S. G. 1982. An Evolutionary Theory of Economic Change. Cambridge, Mass. and London: Belknap Press.

Nelson, Richard R. 2003. On the uneven evolution of human know-how. Research Policy, 32: 909-922.

Nietzsche, Friedrich. 1899. The Works of Friedrich Nietzsche, Volume I, A Genealogy of Morals, Poems. Trans. W. A. Hausmann and J. Gray. London: T. Fisher Unwin.

Noys, Benjamin. 2011. 'Grey in Grey': Crisis, Critique, Change. Journal of Critical Globalisation Studies, 4: 45-60.

Nowotny, H, Scott, P. and Gibbons, M. 2001. Re-Thinking science: Knowledge and the public in an age of uncertainty. Cambridge: Polity.

Nowotny, Stefan. 2003. World Wide World. Is There a World of Anti-Globalism? Transversal: Multilingual Webjournal, 3. http://eipcp.net/transversal/0303/nowotny/en. Accessed 21 July 2013.

Ohmae, Kenichi. 1990. The Borderless World. New York: Harper Business.

Ohmae, Kenichi. 1995. The End of the Nation-State: The Rise of Regional Economies. New York: The Free Press.

Oksala, Johanna. 2010. Foucault's politicization of ontology. Continental Philosophy Review, 43: 445-466.

Ostry, Sylvia and Nelson, Richard. 1995. Techno-Nationalism and Techno-Globalism: Conflict and Cooperation. Washington: Brookings Institution.

Palma, J. G. 2009. The revenge of the market on rentiers. Why neo-liberal reports of the end of the end of history turned out to be premature. Cambridge Journal of Economics, 33: 829-869.

Perez, Carlota. 2002. Technological Revolutions and Financial Capital: The Dynamics of Bubbles and Golden Ages. Cheltenham, UK and Northampton, Mass.: Edward Elgar.

Perez, Carlota. 2004. Technological Revolutions, Paradigm Shifts and Socio-Institutional Change. In E. Reinert (ed.), Globalization, Economic Development and Inequality: An alternative Perspective. Cheltenham, UK and Northampton, Mass., USA: Edward Elgar, 217-242.

Rabinow, Paul. 1996. Essays on the anthropology of reason. Princeton: Princeton University Press.

Ramonet, Ignacio. 1998. Un autre monde est possible. Le Monde Diplomatique, May. http://www.monde-diplomatique. fr/1998/05/RAMONET/10527. Accessed 2 June 2004.

Reinecke, Wolfgang H. 1998. Global Public Policy: Governing Without Government? Washington DC: Brookings. 
Rodrik, D. 2000. Governance of Economic Globalization. In J. Nye and J. Donahue (eds), Governance in a Globalizing World. Cambridge: Brookings Institution Press, 347-366.

Romer, Paul M. 1986. Increasing Returns and Long-Run Growth. Journal of Political Economy, 94 (5): 1002-1037.

Romer, Paul M. 1990. Endogenous Technological Change. Journal of Political Economy, 98 (5): 71-102.

Rosenberg, N. and Frischtak, C. 1994. Technological Innovation and Long waves. In N. Rosenberg (ed.), Exploring the Black Box. Cambridge: Cambridge University Press.

Salomon, J-J., Sagasti, F. R. and Sachs-Jeantet, C. 1994. The Uncertain Quest: Science, Technology and Development. Tokyo: United Nations University Press.

Scholte, Jan Aarte. 2000. Globalization. A critical introduction. London: Palgrave.

Schraube, Ernst. 2005. 'Torturing Things Until They Confess': Günther Anders' Critique of Technology. Science as Culture, $14(1): 77-85$.

Schumpeter, Joseph. 1927. The Explanation of the Business Cycle. Economica, 21 (December): 286-311.

Schumpeter, Joseph. 1935. The Analysis of Economic Change. Review of Economic Statistics, 17 (4): 2-10.

Sloterdijk, Peter. 1997. Dans le même bateau: essai sur l'hyperpolitique. Deshusses, Pierre trans. Paris: Collection Rivages.

Sloterdijk, Peter. 2006. Le palais de cristal: à l'intérieur du capitalisme planétaire. Mannoni, Olivier trans. Paris: Maren Sell Éditeurs.

Solow, Robert. 1957. Technical Change and the Aggregate Production Function. Review of Economics and Statistics, 39: 312-320.

Steger, Manfred B. 2009. Globalisation and Social Imaginaries: The Changing Ideological Landscape of the Twenty-First Century. Journal of Critical Globalisation Studies, 1: 9-30.
Steingard, D. S. and Fitzgibbons, D. E. 1996. Challenging the juggernaut of globalization: a manifesto for academic praxis. Journal of Organizational Change Management, 8 (4): 30-54.

Stiegler, Bernard. 2009. Acting Out. Trans. D. Barison, D. Ross and P. Crogan. Stanford: Stanford University Press.

Stiglitz, Joseph E. 2002. Globalization and Its Discontents. New York: W. W. Norton.

Swiss Federal Institute of Technology. 2007. KOF Index of Globalisation. http://globalization.kof.ethz.ch/. Accessed 23 September 2009

Tassin, Eric. 2003. Contre la mondialisation, une politique du monde. L'Humanité.fr (21 November). http://www. humanite.fr/node/355850. Accessed 21 July 2013.

Tidd, Joe, Bessant, John and Pavitt, Keith. 2005. Managing Innovation: Integrating Technological, Market and Organisational Change (3rd edition). Chichester, UK: John Wiley and Sons.

Tylecote, Andrew. 1991. The Long Wave in the World Economy. London: Routledge.

Virilio, Paul. 1999. Politics of the Very Worst. In conversation with Philippe Petit. New York: Semiotext(e).

Winner, Langdon. 1980. Do artefacts have politics? Daedalus, 109: 121-133.

Winner, Langdon. 1989. The Whale and the Reactor. A Search for Limits in the Age of Technology. Chicago: Chicago University Press.

Winner, Langdon. 1997. The handwriting on the wall: resisting technoglobalism's assault on education. In M. Moll (ed.), Tech High: Globalisation and the Future of Canadian Education. Ottawa: Canadian Centre for Policy Alternatives/Fernwood Publishers, 167-188.

Witt, Ulrich. 2003. Generic features of evolution and its continuity: a transdisciplinary perspective. Theoria, 18 (48): 273-288. 
